\title{
The Effect of Corporate Governance Disclosure on Banking Performance: Empirical Evidence from Iran, Saudi Arabia and Malaysia
}

\author{
Khanifah KHANIFAH $^{*}$, Pancawati HARDININGSIH ${ }^{* *}$, Asri DARMARYANTIKO ${ }^{* * *}$, \\ Iryantika IRYANTIK $^{* * * *}$, Udin UDIN ${ }^{* * * * *}$
}

Received: December 19, 2019 Revised: January 31, 2020 Accepted: February 06, 2020.

\begin{abstract}
A series of corporate failures and financial crises have raised attention to organizational governance issues, especially for financial institutions. In the banking system, corporate governance further plays a unique role because of the uniqueness of the banking organizations. Therefore, this study aims to examine the effect of corporate governance disclosure on bank performance by building a corporate governance disclosure index (CGDI) for 10 Islamic banks operating in Iran, Saudi Arabia and Malaysia. The data used in this study are secondary data taken from annual reports and sourced from the official websites of each banks include Iran Exchange, Stock Market Quotes and Financial News, and Bursa Malaysia. This study uses content analysis of the annual bank report within five years (2014-2018). The results show that Islamic banks comply with $72.4 \%$ of the attributes discussed in the CGDI. The most frequently reported and disclosed elements are board structure and audit committee. The regression results provide evidence that Islamic banks with a higher level of corporate governance disclosure reported high operating performance measured by ROA. In contrast to the expectation, the financial performance of ROE and Tobins'q are not significantly related to the disclosure of sharia bank governance.
\end{abstract}

Keywords: Corporate Governance Disclosure, Sharia Bank, Performance

JEL Classification: E44, M14, Q56

\section{Introduction}

A series of corporate failures and financial crises have raised attention to organizational governance issues, especially for financial institutions. In the banking system, corporate governance plays a unique role because of the uniqueness of this banking organization. These specificities, such as high pressure, heavy regulation, and government intervention, require different analyses of corporate

\footnotetext{
*First Author. Universitas Wahid Hasyim, Indonesia.

${ }^{* *}$ Universitas Stikubank, Indonesia

***Master Scholar of Universitas 17 Agustus 1945 Semarang, Indonesia

****Universitas Wahid Hasyim, Indonesia

$* * * * *$ Corresponding Author. Business and Economic Faculty, Universitas Muhammadiyah Yogyakarta, Indonesia [Postal Address: JI. Brawijaya, Tamantirto, Kec. Kasihan, Yogyakarta, 55183, Indonesia] Tel: +62 85343709228

Email: udin_labuan@yahoo.com

(c) Copyright: The Author(s)

This is an Open Access article distributed under the terms of the Creative Commons Attribution NonCommercial License (https://creativecommons.org/icenses/by-nc/4.0/) which permits unrestricted noncommercial use, distribution, and reproduction in any medium, provided the original work is properly cited.
}

governance issues. Besides, corporate governance has a higher level of importance for banking companies because banks mobilize public savings (Darmadi, 2013; Wahyudi, Sari, Hersugondo, \& Udin, 2019). The current global financial crisis could be associated with failures and weaknesses in corporate governance arrangements in commercial service companies (Chabachib, Yudha, Hersugondo, Pamungkas, \& Udin, 2019).

Islamic banks have the same experience as the collapse of conventional banks, which exposed to corporate governance failures (ul Qayyum \& Norren, 2019; Usman, Andriyani, \& Pambuko, 2019). Compared to conventional banks, Islamic banks have additional risks, such as the risk of managing mudharabah investment funds and the risk of sharia non-compliance (Tabash, 2019). An essential challenge for Islamic banks is to improve the quality of corporate governance. Corporate governance in an Islamic perspective which described as a system to defend the rights of stakeholders from all types of risk as a result of organizational actions. Islamic banks must have a better structure of Islamic compliance. Islamic compliance in Islamic banks refers to the activities and operations of Islamic banks that need to be free from all elements of 
sinful actions, sharia risks, exploitation, and have real economic objectives to finance productive social sectors in the economy.

Besides, to fulfill quality governance, Islamic banks must have high accountability to meet the interests of their stakeholders (shareholders, investment account holders, management, creditors, employees) (Tabash, 2019). Therefore, Islamic banks are expected to be able to inform the corporate governance system to stakeholders. This governance information includes how banks and investments are managed in a manner that is following sharia and prudential principles (Darmadi, 2013; Ifada, Faisal, Ghozali, \& Udin, 2019). Disclosure of corporate governance can improve internal control by corporate stakeholders, who then results in improved company performance. Many empirical studies have highlighted the relationship between governance disclosure and company performance.

Thus, this study conducted empirical research related to corporate governance practices revealed by Islamic banks affecting their performance. Researchers used an assessment of corporate governance practices based on research conducted by (Srairi, 2015). Srairi (2015) has developed a corporate governance category based on corporate governance principles of economic development and cooperation organizations (OECD), guidelines, and standards issued by Islamic financial institutions (AAOIFI) accounting and auditing organizations and Islamic financial services boards (IFSB). Samir Srairi developed the corporate governance disclosure of Islam (CGDI) into 63 items classified in six main categories of governance, namely board structure, risk management, transparency and openness, audit committees, sharia supervisory boards, and investment account holders.

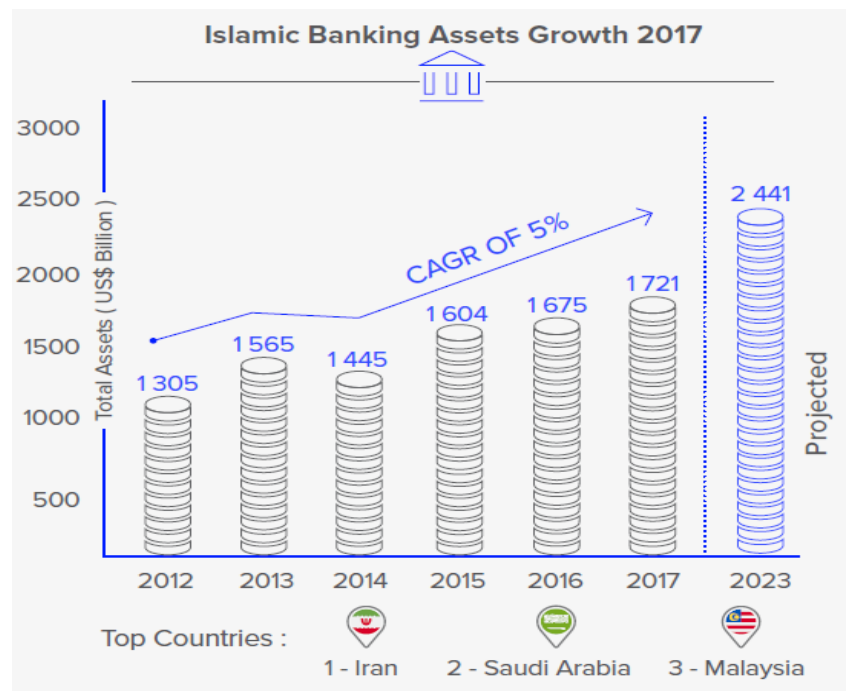

Figure 1: The Growth of Sharia Banking Assets
This study explored the corporate governance disclosure index in annual reports of Islamic banks in Iran, Saudi Arabia, and Malaysia. The Islamic finance development indicator (IFDI) provided ratings. It profiled for different Islamic financial markets throughout the world, using essential factors grouped into five broad areas of development as critical indicators. According to IFDI, the growth of Islamic banking assets is occupied by Iran, Saudi Arabia, and Malaysia.

The total assets of Sharia banking in Saudi Arabia and Malaysia grew 8\% and 16\% (see Figure 1). For Saudi Arabia, the growth is mainly driven by the issuance of domestic and international Sukuk. Meanwhile, Iran has declined in assets as a result of the depreciation of its currency against the US dollar. With the ongoing devaluation of the riyal, Iran's Islamic financial assets are expected to decline further. This is independent of the assets of the country's Islamic financial institutions, as reported in local currencies grew 13\% in 2017.

The relationship between corporate governance and company performance has been studied in-depth in several financial kinds of literature (Hersugondo \& Udin, 2019; Khajar, Hersugondo, \& Udin, 2018; Srairi, 2015). Analysis of the performance of Islamic banking has been done before (Antonio, Sanrego, \& Taufiq, 2012; Meilani, Andraeny, \& Rahmayati, 2016; Mohammed \& Taib, 2015; Mutia \& Musfirah, 2017).

Javaid and Saboor (2015) developed the corporate governance composite index based on 21 proxies to analyze the impact of the corporate governance index on company performance as measured by ROA, ROE, and Tobins'q of 58 registered Pakistani manufacturing companies from 2009-2013. The index is divided into three sub-indices, namely the board structure, ownership structure, and disclosure. The results found that the corporate governance index (CGI) and company performance have a positive and significant relationship, but the relationship for each specific index depends on the size of the company's performance. Sub-index 1 board structure was found to have a positive and significant relationship with all three performance measures. Sub-index 2 ownership structure was found to have a significant positive relationship with only accounting measures based on firm performance. On the other hand, sub-index 3 ownership only had a significant relationship with ROA. The results also found that companies that have strong corporate governance mechanisms have greater opportunities to obtain external finance.

Cunha and Mendes (2017) analyzed financial determinants of the level of corporate governance disclosure (CGD) in a large sample of Portuguese companies, listed in the Lisbon Euronext index, in the period between 2005 and 2011. They built an index, 
consisting of a total of 82 corporate governance attributes that are grouped into six information categories: management structure, special committee (remuneration and appointment); audit and risk management; ownership structure; company compliance and responsibility; and financial transparency. The results of the ordinal logistic model show that company size and growth opportunities, as measured by Tobin's Q, have a significant and positive influence on corporate governance disclosure. However, the results of their study found that there was no relationship between corporate governance disclosure and financial performance as measured by ROE.

Javaid and Saboor (2015) empirically investigated the relationship of corporate governance and company performance in terms of accounting and market performance to be measured by Return on Assets, Return on equity, and Tobin's Q. The results require that the corporate governance index (CGI) and company performance have a relationship positive and significant, but the relationship for each specific index depends on the size of the company's performance. The results also show that companies that have strong corporate governance mechanisms have greater opportunities to obtain finance.

\section{Literature Review}

\subsection{Agency Theory}

Agency theory states that managers, as shareholder agents must disclose all relevant information through company disclosures because the board of directors and shareholders do not oversee operational decisions and routine activities (Fama \& Jensen, 1983; Jensen, 1993). By disclosing both mandatory and voluntary information, managers can reduce agency costs and increase their trust in shareholders and the board of directors. In addition, company disclosure helps to develop a positive company image and bring long-term benefits (Armitage \& Marston, 2008; Mahadeo, Oogarah-Hanuman, \& Soobaroyen, 2011).

Research has shown that corporate information disclosure plays an important role in minimizing information asymmetry and reducing agency problems (Cormier, Ledoux, \& Magnan, 2011). In particular, the publication of information, both mandatory and voluntary for the capital market, will help companies to reduce capital costs, gain investor confidence, and increase the value of the stock market (Mahadeo et al., 2011), (Baimukhamedova, Baimukhamedova, \& Luchaninova, 2017; Lee \& Chae, 2018). Hardiningsih, Januarti, Yuyetta, Srimindarti, and Udin (2020), Perrini, Russo, Tencati, and Vurro (2011) conclude that revealing more information and thus reducing asymmetric information can reduce the cost of the company capital. Arcay and Vázquez (2005) found that companies that increase disclosure decrease Bid-Ask spreads, which have links to asymmetric information. Haniffa and Hudaib (2006) found a negative relationship between disclosure in the annual report and the cost of capital for the company.

\subsection{Corporate Governance Disclosure Index Factors}

\subsubsection{The Relationship between Board of Directors and Banking Performance}

The board of directors is considered as an important tool to protect shareholders and help control managers when they try to maximize their own interests at the expense of the company's profitability. Board structure, composition, size, and characteristics have a direct influence on organizational performance (Abatecola, Farina, \& Gordini, 2014; Kumar \& Singh, 2013). Agency theory suggests that there are a number of mechanisms to reduce agency problems in companies include choosing the appropriate board composition (in terms of size, sex, experience, and competence), effective audit committees, and shooting threats (Tandelilin, Kaaro, Mahadwartha, \& Supriyatna, 2007). Resource-based anticipation that a larger and more diversified council will gather additional and more diverse knowledge (Adams \& Mehran, 2003). This will lead to better governance and consequently will improve company performance (Fuenzalida, Mongrut, Arteaga, \& Erausquin, 2013), although some empirical results contradict this popular belief (Adams \& Mehran, 2003). Using a sample of 25 Canadian companies, Bozec and Dia (2015) found a negative relationship between the percentage of independent directors and company performance. However, other studies have argued that the percentage of independent directors is positively related to company performance. Weir, Laing, and McKnight (2002) found a positive relationship between the percentage of independent directors and company performance using a sample of the largest UK companies. Ho and Williams (2003) reported a positive relationship between the percentage of independent directors and the physical and intellectual capital performance of companies in 84 companies registered in South Africa in 1998.

\subsubsection{The Relationship between Risk Management and Banking Performance}

For effective risk management at the bank level, the board of directors must establish a risk management division that is independent of other bank units (Chapra, 2007). This committee with independent members has a mission to identify, measure, monitor, and control various types of risk (market risk, credit risk, liquidity risk, operational risk, legal risk, compliance risk, reputation risk) 
carried out by Islamic banks (Darmadi, 2013). The existence of a risk management committee is expected to improve risk management and to increase bank value. However, this result was not confirmed by the study of Aebi, Sabato, and Schmid (2012), which found a negative effect on the existence of a risk management committee and ROE.

\subsubsection{The Relationship between Audit Committee and Banking Performance}

The audit committee is one of the most important governance mechanisms responsible for ensuring that the bank produces relevant, adequate and credible information that is released on time to shareholders, creditors, investors, and other stakeholders (Sarkar, Sarkar, \& Sen, 2012). The audit committee is responsible for increasing and maintaining the independence of internal auditors (Pathan, Skully, \& Wickramanayake, 2007). In addition, the audit committee also has the responsibility of ensuring that the external auditor receives all information needed to carry out the audit process independently and effectively, not subject to the pull of interest and pressure from the company's internal management. To play this role, independence, size, and financial expertise are important issues for the audit committee. In most countries, regulations require that audit committees have at least two-thirds of their members as independent directors. Banks that have a larger audit committee are committed to seeing that a quality accounting process already exists. Therefore, a larger audit committee can lead to a higher level of transparency, thus providing strong monitoring (Anderson, Mansi, \& Reeb, 2004). There is an obligation that audit committee members, or at least one of them, must have financial or accounting expertise to understand the technical and control issues related to internal and external audits.

\subsubsection{The Relationship between Sharia Supervisory Board and Banking Performance}

Every Islamic financial institution must form a supervisory board called the Shariah Supervisory Board (SSB), which acts as an additional layer of government oversight. The first role of the sharia supervisory board is to ensure that the bank operates in accordance with sharia law. In addition, according to Hassan and Mollah (2014), the sharia supervisory board acts as an independent control mechanism in holding the board of directors or other governance agents from being involved in excessive risktaking. Furthermore, the sharia supervisory board as an internal governance mechanism will encourage management to be transparent, including disclosure on corporate governance. Farook, Kabir Hassan, and Lanis (2011) investigate the determinants of corporate social responsibility disclosure from Islamic banks found that the characteristics of sharia supervisory boards influence the level of social disclosure. As external auditors, the sharia supervisory board is independent of bank operations. So that the sharia supervisory board is not subject to instructions and influence by management, the board of directors, or shareholders (Nienhaus, 2012).

To improve the function of the sharia supervisory board, AAOIFI (Vinnicombe, 2010) has published a set of governance standards related to the composition and role of the sharia supervisory board. For example, each board must consist of at least three members. The board must produce an annual report, which must be published with the bank's financial statements (Vinnicombe, 2010). However, in the absence of the obligation to implement these standards throughout the industry, the roles and responsibilities of the sharia supervisory board vary for each sharia bank. Because the role of the sharia supervisory board is limited to reviewing bank contracts before their implementation (exante), AAOIFI proposes to banks to have a kind of internal audit function known as internal sharia review (ISR). This ISR structure verifies the execution of contracts (ex-post), and the sharia supervisory board will tend to rely on ISR findings to publish their reports to shareholders.

\subsubsection{The Relationship between Investment Account Holders (IAHS) and Banking Performance}

Investment Account Holders play a role in the company's performance because companies can use Investment Account Holders to carry out operational activities or other company activities. Farook et al. (2011) explained that Islamic bank accounts are more accessible than shares, even though customers do not have formal voting rights, but can still influence the level of supervision of management through shareholders.

In the view of legitimacy, investment account holders affect legitimacy. With a large number of investment account holders in the banking sector, there is an increasing level of public confidence in banks due to a large number of investment account holders in the banking industry. The more investment account holders there are in a bank, the more the level of disclosure and supervision is carried out. The increasing number of investment account holders automatically the level of public confidence in a bank can be said to be good. The ownership structure is an important factor that can affect company performance. Thus, this study proposes hypotheses (see Figure 2):

H1: Disclosure of governance has a positive effect on performance of Islamic banking (ROA).

H2: Disclosure of governance has a positive effect on performance of Islamic banking (ROE).

H3: Disclosure of governance has a positive effect on performance of Islamic banking (Tobins'q). 


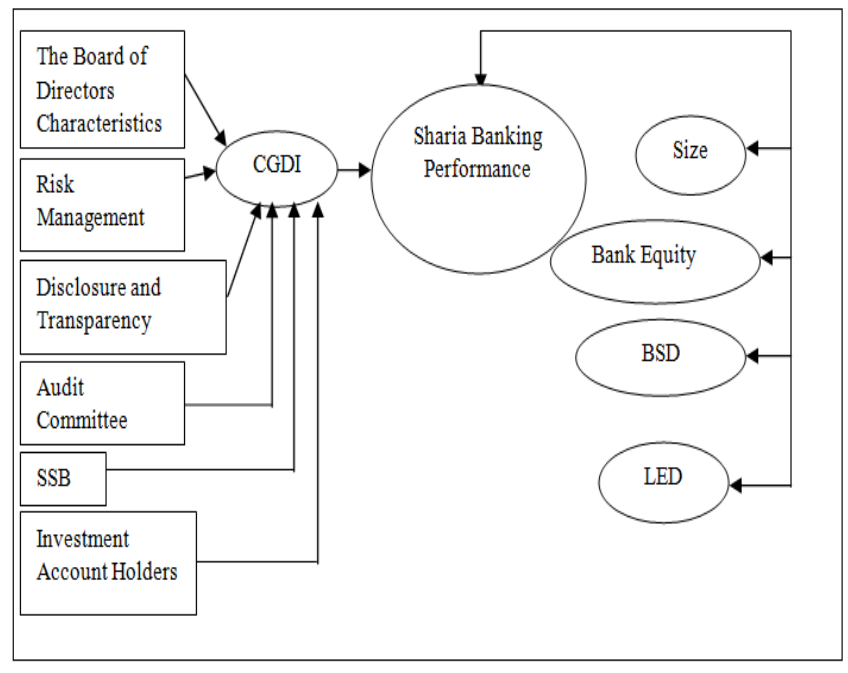

Figure 2: Conceptual Framework

\section{Research Design and Methodology}

\subsection{Variables and Operational Definition}

In this research, the dependent variables are banking performance measured using Tobin's Q, Return Asset (ROA), and Return on Equity (ROE), while the independent variable is corporate governance disclosure index (CGDI), which is classified in six main categories of governance, namely board structure, risk management, transparency and openness, audit committees, sharia supervisory boards, and investment account holders. This study also uses control variables, namely bank-specific variables (size and bank equity) and financial and economic indicators (banking sector development and level of economic development).

A polarizing perspective of $\mathrm{CG}$ has developed between the perspective of shareholding and stakeholding. CGDI is an index of CG disclosure. In some previous studies (AlMalkawi, Pillai, \& Bhatti, 2014; Darmadi, 2013), in scoring items, CGDI was developed using a dichotomy, which scores 1 if the bank discloses an item and 0 if not, without penalty for each item that is kept secret. All items have the same weight.

Srairi (2015) establishes CGDI for sharia commercial banks in the GCC countries. In measuring CGDI in this study conducted on Islamic banks in Iran, Malaysia, and Saudi Arabia. The first step is to calculate the index sub for each of the six components of corporate governance and then do an average assessment of the value of the six subindex as CGDI for each bank. The higher the index, the more transparent the bank is in presenting corporate governance practices in the annual report. In the second step, the calculated scores for each bank are summed, and then the average is calculated to find the overall CGDI for the whole country.

This study based on the standard developed by Srairi (2015), build governance index consisting of 63 items divided into six components as follows: 15 items on board structure disclosure, 13 items on risk management, 9 items on transparency and disclosure, 8 items disclosure about the audit committee, 10 items disclosure about the sharia supervisory board and 8 items disclosure about the investment account holder. This study used an unweighted index because this approach has the advantage of treating each attribute under the sub-index symmetrically without having to make a subjective assessment of the relative importance of each attribute (Sarkar et al., 2012).

Scores will be calculated for each bank and for each dimension of corporate governance as follows:

$$
C G D I_{j}=\frac{\sum_{i=1}^{n j} X i j x 100}{n j}
$$

CGDIj represents corporate governance for bank $\mathrm{j}, \mathrm{Xij}=$ 1 , if the bank discloses the item and 0 if the item is not disclosed, $n j$ is the number of items expected by the bank. Theoretically, CGDI can range from 0 to $100 \%$. Banks that report all 63 items will get a score of $100 \%$. We calculate CGDI for each country in two steps. In the first step, we calculate the sub-indices for each of the six components of corporate governance, and then we average the values of the six sub-indices to find the CGDI of each bank. The higher the index, the more transparent the bank is in disseminating information about corporate governance practices in the annual report. In the second step, the scores calculated for each bank in each country are added together, and then the average is calculated to find the overall CGDI for the whole country.

This study uses secondary data taken from annual reports on each of the sharia bank websites in Iran, Saudi Arabia, and Malaysia in the 2014-2018 period.

\subsection{Sample and Population}

The population of this study is Islamic commercial banks in Iran, Saudi Arabia, and Malaysia in 2014-2018. The sample in this study will be taken by purposive sampling with the following considerations:

Annual report data considerations:

(1) The research sample will be taken from the company's financial statement data published on the web of each Islamic bank.

(2) The sample in this study is a Sharia Commercial Bank 
(3) The company publishes its financial statements in a row from 2014-2018.

Other data considerations:

(1) The annual share price of a bank is obtained from the capital market.

(2) Macroeconomic data and structure of the banking industry are obtained from annual reports from the central banks of each country and international financial statistics (IFS).

\subsection{Data Collection}

The data used in this study are secondary data taken from annual reports and sourced from the official websites of each bank and supplemented with data from Islamic Banks and completed from the Iran exchange website (www.tse.ir), Stock Market Quotes and Financial News (www.investing.com) and Bursa Malaysia (www.bursamalaysia.com) during the 2014-2018 period. Then based on sample selection criteria, CGDI is calculated as a proxy for CG disclosure as a proxy for measuring bank performance and calculating control variables.

As an internal determinant, this study considers three bank characteristics related to bank size, bank equity, and bank risk. Bank size is proxied by the logarithm of the bank's total assets in millions of rupiah. Size may be an important determinant of bank performance if there is an increase in scale in banking. Bank equity is calculated as the book value of equity divided by total assets. According to the banking literature, this variable can affect bank performance positively (Srairi, 2015).

As an external determinant, this study uses two factors related to the financial industry and the macroeconomic environment. As a financial industry variable, researchers examine the impact of developing the banking sector. In this study, the observed financial industry variable is the impact of the development of the banking sector. The variable impact of the development of the banking sector is proxied by a credit to the private sector divided by GDP. This ratio is expected to have a positive impact on performance. This research model is also controlled by the level of economic development, namely, GDP per capita.

\subsection{Data Analysis}

Analysis of the data used in this study is a simple threestep linear regression analysis (3SLS) with the classic assumption test first. To estimate the impact of corporate governance on Islamic bank performance, the data analysis technique used is a simple three-step OLS regression.

\section{Results and Discussion}

\subsection{Research Object Description}

The object used in this study at the Islamic Banking Bank in Iran, Malaysia, Saudi Arabia period 2014-2018. This study looks at the effect of the Corporate Governance Disclosure Index (CGDI) on banking performance as measured by Return on Assets (ROA), Return on Equity (ROE), and Tobin's Q. Ratio data obtained according to the observation period are obtained from the website of each Islamic banks in Iran, Malaysia, Saudi Arabia. The population in this study is Sharia Banks in Iran, Malaysia, and Saudi Arabia, amounting to 10 banks (see Table 1).

Table 1: List of Sharia Bank Research Samples in Three Countries

\begin{tabular}{|c|c|c|}
\hline No. & Bank Name & Country \\
\hline 1 & Bank Pasargad & Iran \\
\hline 2 & Bank Tejarat & Iran \\
\hline 3 & Bank Al Rajhi & Saudi Arabia \\
\hline 4 & Bank Al Jazira & Saudi Arabia \\
\hline 5 & Bank National Arab & Saudi Arabia \\
\hline 6 & Bank Riyadh & Saudi Arabia \\
\hline 7 & Affin Islamic Bank & Malaysia \\
\hline 8 & CIMB Islamic Bank & Malaysia \\
\hline 9 & Maybank & Malaysia \\
\hline 10 & RHB Islamic Bank & Malaysia \\
\hline
\end{tabular}

\subsection{Descriptive Analysis}

Table 2 reports the overall average CGDI value for each country and further shows the scores of each country in the six dimensions of corporate governance. As can be seen from this table, Saudi Arabia shows the highest CGDI, with a score of $74.35 \%$. This means that Sharia Banking in Saudi Arabia revealed about $74.35 \%$ of the 63 items, which formed the corporate governance index. Followed later by Malaysia, it revealed corporate governance of $72.08 \%$. On the other hand, Iran seems to have the lowest CGDI, scoring $70.87 \%$. Given the overall CGDI average of $72.43 \%$, it can be seen that Saudi Arabia and Malaysia have above average CGDI. However, it should be noted that all countries in the sample had an average CGDI of more than $50 \%$.

Table 3 informs that the average growth of CGDI (X1) is $73.18 \%$ with a standard deviation (std deviation) of $8.91 \%$, which means the average value is greater than the standard deviation, thus indicating good results. Meanwhile, the average ROA (Y) is $1.16 \%$ with a standard deviation (std deviation) of $0.82 \%$ which means that the variable ROA has 
a small distribution because the standard deviation is smaller than the mean (mean), so the deviation of data at This ROA variable can be said to be good.

Table 2: Statistics on Banking Governance Disclosure Index by Dimension and Country

\begin{tabular}{|c|c|c|c|c|}
\hline $\begin{array}{c}\text { Corporate } \\
\text { governance } \\
\text { dimension }\end{array}$ & Iran & Malaysia & $\begin{array}{c}\text { Arab } \\
\text { Saudi }\end{array}$ & $\begin{array}{c}\text { Average } \\
\text { of } \\
\text { CGDI }\end{array}$ \\
\hline Board Structure & 86.67 & 76.67 & 86.67 & 83.33 \\
\hline Risk Management & 80.77 & 73.08 & 69.23 & 74.36 \\
\hline $\begin{array}{c}\text { Transparency and } \\
\text { Measurement }\end{array}$ & 77.78 & 83.33 & 83.33 & 81.48 \\
\hline $\begin{array}{c}\text { Audit Committee } \\
\text { Sharia Supervisory } \\
\text { Board }\end{array}$ & 75.00 & 84.38 & 90.63 & 83.33 \\
\hline $\begin{array}{c}\text { Investment Account } \\
\text { Holders }\end{array}$ & 50.00 & 62.50 & 56.25 & 56.25 \\
\hline Overall Index & 70.87 & 72.08 & 74.35 & 72.43 \\
\hline Overall Rank & 3 & 2 & 1 & 55.83 \\
\hline
\end{tabular}

The average ROE (Y3) is $10.70 \%$ with a standard deviation (std deviation) of 5.27\%, which means that the variable ROE has a small distribution because the standard deviation is smaller than the mean (mean), so the deviation of data at This ROA variable can be said to be good. Then, Tobins'q (Y3) the average is $0.98 \%$ with a standard deviation (std deviation) 1.91\% which means that Tobins'q has a large distribution because the standard deviation is greater than the average value (mean) so that the deviation of data on Tobins'q can be said to be not good.

Table 3: Descriptive Statistics

\begin{tabular}{|c|c|c|c|}
\hline & Mean & Std. Deviation & N \\
\hline ROA & 1.1564 & .81998 & 50 \\
\hline ROE & 10.6956 & 5.27388 & 50 \\
\hline TOBINS'Q & .9760 & 1.90687 & 50 \\
\hline GCDI & 73.1802 & 8.91495 & 50 \\
\hline SIZE & 17.5826 & 3.16475 & 50 \\
\hline EKUITAS & 21.8152 & 54.92150 & 50 \\
\hline PSP & .7126 & 1.71266 & 50 \\
\hline PDB & 16.25 & 10.56 & 50 \\
\hline
\end{tabular}

For the control variable (size), it is found that the average is $17.58 \%$ with a standard deviation (std deviation) of $3.16 \%$, which means the average value is greater than the standard deviation, thus indicating good data distribution results. Meanwhile, for the bank equity, the average is
$21.82 \%$ with a standard deviation (std deviation) of $54.92 \%$, which means the bank equity has a large distribution because the standard deviation is greater than the average value (mean) thus indicating good data distribution results. For PSP, it is found that the average is $0.71 \%$ with a standard deviation (std deviation) of $1.71 \%$, which means the average value is smaller than the standard deviation, thus indicating the results of data distribution is not good. For GDP, an average of $16.25 \%$ with a standard deviation (std deviation) of $10.56 \%$, which means the average value is greater than the standard deviation, thus indicating the results of good data distribution.

\subsection{Classical Assumption Test}

Before testing the hypothesis with the t-test, the classic assumption deviation test is performed first. This test is carried out to test the validity of the results of multiple linear analyzes. The tests used are the normality test, multicollinearity test, autocorrelation test, and heteroscedasticity test.

Based on the histogram test, all data in this study were normally distributed. Based on the multicollinearity test results obtained, the results of VIF values of all variables $<10$ and tolerance values of more than 0.1 so that it can be said that this study did not occur multicollinearity or correlation between independent variables. Testing the presence or absence of autocorrelation is done using the Durbin-Waston method. From all tests conducted on the dependent variables ROA, ROE, and Tobins' Q, there are no autocorrelations. Likewise, for the heteroscedasticity test, significance values of CGDI 0.635, SIZE 0.446, Bank Equity 0.122 , PSP 0.000 , and GDP 0.001 were obtained. The significance value of the five variables $>0.05$, it can be concluded that there is no heteroscedasticity.

\subsection{Hypothesis Test}

T-test results on CGDI (X), as in Table 4, obtained a tcount of -2.603 with a significant value of 0.013 whose value was far below 0.05 . Thus $\mathrm{H} 1$ was accepted, meaning that there was a significant influence on CGDI (X) partially on ROA (Y1). While the results of the t-test on the control variables (size and equity) were significant values of 0.287 and 0.272 , respectively, meaning that there was no significant influence of size and equity partially on ROA. Meanwhile, PSP and GDP significant value respectively 0.021 AND 0.00 means that there is a significant influence of PSP and GDP partially on ROA (Y1).

T-test results on CGDI (X), as in Table 5, obtained a tcount of -1.222 with a significant value of 0.226 . This value was well above 0.05 . Thus $\mathrm{H} 2$ was rejected, meaning that there was no significant influence on CGDI (X) partially on 
ROE (Y2).

Table 4: T-Test Results for ROA

\begin{tabular}{|c|c|c|c|c|c|c|}
\hline \multirow{2}{*}{\multicolumn{2}{|c|}{ Model }} & \multicolumn{2}{|c|}{ Unstandardized Coefficients } & \multirow{2}{*}{$\begin{array}{c}\text { Standardized Coefficients } \\
\text { Beta } \\
\end{array}$} & \multirow{2}{*}{$\mathbf{t}$} & \multirow{2}{*}{ Sig. } \\
\hline & & B & Std. Error & & & \\
\hline \multirow{6}{*}{1} & ROA & 1.106 & 1.129 & & .980 & .332 \\
\hline & CGDI & -.029 & .011 &,- 310 & -2.603 & .013 \\
\hline & SIZE & .050 & .047 & .194 & 1.079 & .287 \\
\hline & EKUITAS & .003 & .003 & .195 & 1.112 & .272 \\
\hline & PSP & .165 & .069 & .345 & 2.392 & .021 \\
\hline & PDB & 6.868 & .000 & .853 & 5.365 & .000 \\
\hline
\end{tabular}

ROA $=1.106-0.029$ CGDI +0.050 SIZE +0.003 EKUITAS + 0.165 PSP + 6.868 PDB

Table 5: T-Test Results for ROE

\begin{tabular}{|c|c|c|c|c|c|c|}
\hline \multirow{2}{*}{\multicolumn{2}{|c|}{ Model }} & \multicolumn{2}{|c|}{ Unstandardized Coefficients } & \multirow{2}{*}{$\frac{\text { Standardized Coefficients }}{\text { Beta }}$} & \multirow{2}{*}{$\mathbf{t}$} & \multirow{2}{*}{ Sig. } \\
\hline & & B & Std. Error & & & \\
\hline \multirow{6}{*}{1} & ROE & 13,859 & 8,702 & & 1,593 & ,118 \\
\hline & CGDI &,- 104 & 085 &,- 175 & $-1,228$ & 226 \\
\hline & SIZE &, 044 &, 360 & ,026 &, 121 & ,904 \\
\hline & EKUITAS &,- 013 & 020 &,- 139 &,- 659 &, 513 \\
\hline & PSP &,- 150 &, 532 &,- 049 &,- 282 & ,779 \\
\hline & PDB & 2,602 &, 000 &, 503 & 2,636 & 012 \\
\hline
\end{tabular}

$\mathrm{ROE}=13.859-(-0.104) \mathrm{CGDI}+0.044 \mathrm{SIZE}+(-0.013) \mathrm{EQUITY}+(-2.620) \mathrm{PSP}+6.602$ PDB

While the t-test results on the control variables (size, equity, and PSP) significant values respectively of 0.904 , 0.513 , and 0.779 , meaning that there is no significant effect of size, equity, and PSP partially on ROE (Y1). Meanwhile, on the GDP control variable, a significant value of 0.012 means that there is a significant influence of the GDP partially on ROE (Y2).

Table 6: T-Test Results for Tobin's Q

\begin{tabular}{|c|c|c|c|c|c|c|}
\hline \multirow{2}{*}{\multicolumn{2}{|c|}{ Model }} & \multicolumn{2}{|c|}{ Unstandardized Coefficients } & \multirow{2}{*}{$\begin{array}{c}\text { Standardized Coefficients } \\
\text { Beta }\end{array}$} & \multirow{2}{*}{ t } & \multirow{2}{*}{ Sig. } \\
\hline & & B & Std. Error & & & \\
\hline \multirow{2}{*}{1} & (Constant) & $-7,520$ & 2,956 & & $-2,544$ &, 015 \\
\hline & CGDI & ,004 & 029 & 021 & 153 & 879 \\
\hline & SIZE & ,329 &, 122 &, 546 & 2,690 &, 010 \\
\hline & EKUITAS & ,006 & 007 & , 163 &, 825 & ,414 \\
\hline & PSP & ,094 &, 181 & 084 &, 519 & 607 \\
\hline & PDB & 1,411 &, 000 & ,754 & 4,209 &, 000 \\
\hline
\end{tabular}

Tobins'q $=(-7.520)-0.004$ CGDI + 0.329 SIZE + 0.006 EKUITAS + 0.094 PSP + 1.411 PDB

T-test results on CGDI (X), as in Table 6, data obtained a t-count of 0.153 with a significant value of 0.879 whose value is well above 0.05 . Thus $\mathrm{H} 3$ was rejected, meaning that there was no significant effect of the CGDI (X) variable partially on Tobins'q (Y3). While the results of the t-test on the SIZE and GDP as control variables are significant values of 0.010 and 0,000 , respectively, meaning that there is a significant influence of the SIZE and GDP variables partially on Tobins'q (Y1). Meanwhile, the control variables EQUITY and PSP significant values respectively of 0.414 and 0.607 , meaning that there is no significant influence of the EQUITY and PSP partially on Tobins' $\mathrm{q}$ (Y3). 


\subsubsection{Coefficient of Determination $\left(R^{2}\right)$ Test}

First, the adjusted $\mathrm{R}$ Square calculation resulted in $43.1 \%$. This illustrates that banking performance, as measured by ROA of $43.1 \%$, is influenced by CGDI, while the remaining $56.9 \%$ is influenced by other factors not examined. Second, the amount of Adjusted R Square for the dependent variable ROE is 0.182 or $18.2 \%$. This illustrates that banking performance, as measured by ROE of $18.2 \%$, is influenced by CGDI, while the remaining $81.8 \%$ is influenced by other factors not examined. Third, the amount of Adjusted R Square for Tobins' Q dependent variable is 0.278 or $27.8 \%$. This illustrates that the performance of banks, as measured by Tobins'q of $27.8 \%$, is influenced by CGDI, while the remaining $72.2 \%$ is influenced by other factors not examined.

Based on the findings of this study, H1 states that CGDI partially does not affect profitability. This is evidenced by $t$ arithmetic of $-1,228$ with a significant value of 0.226 so that this $\mathrm{H} 1$ is accepted. This means that the CGDI has a significant effect on ROA. The result of this study is consistent with the previous studies conducted by (Javaid \& Saboor, 2015; Srairi, 2015) that CGDI partially had a significant effect on ROA.

H2 states that CGDI partially has no effect on ROE. This is proven by a count of $-1,228$ with a significant value of 0.226 , whose value is well above 0.05 so that $\mathrm{H} 2$ is rejected. It means that the CGDI has no significant effect on ROE. The result of this study is consistent with the previous study conducted by Cunha and Mendes (2017) that CGDI partially had no significant effect on ROE.

$\mathrm{H} 3$ states that musharaka financing partially has no effect on Tobins'q. This is evidenced by a t count of 0.153 with a significant value of 0.879 , that value is well above 0.05 so that $\mathrm{H} 3$ is rejected. This means that CGDI has no significant effect on Tobins'q. The result of this study is consistent with the previous study conducted by Srairi (2015) that CGDI partially has no significant effect on Tobins'q.

\section{Conclusion}

The conclusions of this study shows that Islamic banks comply with $72.4 \%$ of the attributes discussed in the CGDI. The most frequently reported and disclosed elements are board structure and audit committee. The regression results provide evidence that Islamic banks with a higher level of corporate governance disclosure reported high operating performance measured by ROA. The financial performance of ROE and Tobins'q are not significantly related to the disclosure of sharia bank governance.

The limitations of this study are as follows:

The period under observation is only five years, so it has not been able to see greater results. This research is only limited to a few banks in Iran, Saudi Arabia, and Malaysia. Data from one of the research variables, namely Tobins'q is only available in 2017 and 2018.

The suggestions for further research are as follows:

For further research, in order to increase the number of variables and also the study period so that it is not limited to the variables and periods in this study, but can be added to the number. CG variables can be examined one by one according to its dimensions so that it can be seen from six dimensions, which dimensions most strongly influence the performance of sharia banking.

\section{References}

Abatecola, G., Farina, V., \& Gordini, N. (2014). Board effectiveness in corporate crises: lessons from the evolving empirical research. Corporate Governance, 14(4), 531-542.

Adams, R. B., \& Mehran, H. (2003). Is corporate governance different for bank holding companies? Economic Policy Review, 9(1), 123-142. Retrieved from https://ssrn.com/abstract $=795584$.

Aebi, V., Sabato, G., \& Schmid, M. (2012). Risk management, corporate governance, and bank performance in the financial crisis. Journal of Banking \& Finance, 36(12), 3213-3226.

Al-Malkawi, H.-A. N., Pillai, R., \& Bhatti, M. (2014). Corporate governance practices in emerging markets: The case of GCC countries. Economic Modelling, 38, 133-141.

Anderson, R. C., Mansi, S. A., \& Reeb, D. M. (2004). Board characteristics, accounting report integrity, and the cost of debt. Journal of Accounting and Economics, 37(3), 315-342.

Antonio, M. S., Sanrego, Y. D., \& Taufiq, M. (2012). An analysis of Islamic banking performance: Maqashid index implementation in Indonesia and Jordania. Journal of Islamic Finance, 176(813), 1-18.

Arcay, M. R. B., \& Vázquez, M. F. M. (2005). Corporate characteristics, governance rules and the extent of voluntary disclosure in Spain. Advances in Accounting, 21, 299-331.

Armitage, S., \& Marston, C. (2008). Corporate disclosure, cost of capital and reputation: Evidence from finance directors. The British Accounting Review, 40(4), 314-336.

Baimukhamedova, A., Baimukhamedova, G., \& Luchaninova, A. (2017). Financial disclosure and the cost of equity capital: The empirical test of the largest listed companies of Kazakhstan. Journal of Asian Finance, Economics and Business, 4(3), 5-17. http://dx.doi.org/10.13106/jafeb.2017.vol4.no3.5

Bozec, R., \& Dia, M. (2015). Governance practices and firm performance: Does shareholders' proximity to management matter? International Journal of Disclosure and Governance, 12(3), 185-209.

Chabachib, M., Yudha, A., Hersugondo, H., Pamungkas, I. D., \& Udin, U. (2019). The Role of Firm Size on Bank Liquidity and Performance: A Comparative Study of Domestic and Foreign Banks in Indonesia. International Journal of Economics and Business Administration, 7(3), 96-105.

Chapra, M. U. (2007). The Islamic vision of development in the 
light of Maqāsid al-sharī 'ah. Jeddah: Islamic Research and Training Institute.

Cormier, D., Ledoux, M.-J., \& Magnan, M. (2011). The informational contribution of social and environmental disclosures for investors. Management Decision, 49(8), 12761304.

Cunha, V. L. M., \& Mendes, S. M. D. (2017). Financial Determinants of Corporate Governance Disclosure: Portuguese Evidence. Athens Journal of Business and Economics, 3(1), 21-36.

Darmadi, S. (2013). Corporate governance disclosure in the annual report: An exploratory study on Indonesian Islamic banks. Humanomics, 29(1), 4-23.

Fama, E. F., \& Jensen, M. C. (1983). Agency problems and residual claims. The Journal of Law and Economics, 26(2), 327-349.

Farook, S., Kabir Hassan, M., \& Lanis, R. (2011). Determinants of corporate social responsibility disclosure: The case of Islamic banks. Journal of Islamic Accounting and Business Research, 2(2), 114-141.

Fuenzalida, D., Mongrut, S., Arteaga, J. R., \& Erausquin, A. (2013). Good corporate governance: Does it pay in Peru? Journal of Business Research, 66(10), 1759-1770.

Haniffa, R., \& Hudaib, M. (2006). Corporate governance structure and performance of Malaysian listed companies. Journal of Business Finance \& Accounting, 33(7-8), 1034-1062.

Hardiningsih, P., Januarti, I., Yuyetta, E. N., Srimindarti, C., \& Udin, U. (2020). The Effect of Sustainability Information Disclosure on Financial and Market Performance: Empirical Evidence from Indonesia and Malaysia. International Journal of Energy Economics and Policy, 10(2), XXX. [Forthcoming] https://doi.org/10.32479/ijeep.8520

Hassan, M. K., \& Mollah, S. (2014). Corporate governance, risktaking and firm performance of Islamic banks during global financial crisis. Finance and Development in Islamic Economies Conference, September 2014, 1-36. DOI:10.1007/s10693-016-0245-2

Hersugondo, H., \& Udin, U. (2019). Corporate governance and corporate value: The mediating role of investment effectiveness base on human capital. Quality - Access to Success, 20(171), 56-61.

Ho, C.-A., \& Williams, S. M. (2003). International comparative analysis of the association between board structure and the efficiency of value added by a firm from its physical capital and intellectual capital resources. The International Journal of Accounting, 38(4), 465-491.

Ifada, L. M., Faisal, F., Ghozali, I., \& Udin, U. (2019). Company attributes and firm value. Evidence from companies listed on Jakarta Islamic index. Espacios, 40(37), 11. [Online Journal]. Retrieved from

https://www.revistaespacios.com/a19v40n37/a19v40n37p11.p df

Javaid, F., \& Saboor, A. (2015). Impact of Corporate Governance index on Firm Performance: evidence from Pakistani manufacturing sector. Journal of Public Administration and Governance, 5(2), 1-21.

Jensen, M. C. (1993). The modern industrial revolution, exit, and the failure of internal control systems. the Journal of Finance, $48(3), 831-880$.
Khajar, I., Hersugondo, H., \& Udin, U. (2018). Antecedents and Outcomes of Corporate Governance: Evidence from Indonesia. European Research Studies Journal, 21(4), 480-492.

Kumar, N., \& Singh, J. (2013). Effect of board size and promoter ownership on firm value: some empirical findings from India. Corporate Governance: The International Journal of Business in Society, 13(1), 88-98.

Lee, A.-Y., \& Chae, S.-J. (2018). The effect of management disclosure and analysis on the stock crash risk: Evidence from Korea. Journal of Asian Finance, Economics and Business, 5(4), 67-72. http://doi.org/10.13106/jafeb.2018.vol5.no4.67

Mahadeo, J. D., Oogarah-Hanuman, V., \& Soobaroyen, T. (2011). A longitudinal study of corporate social disclosures in a developing economy. Journal of Business Ethics, 104(4), 545558.

Meilani, S. E. R., Andraeny, D., \& Rahmayati, A. (2016). Analisis kinerja perbankan syariah di Indonesia dengan menggunakan pendekatan islamicity indices. Syariah Paper Accounting FEB UMS Conference. Retrieved from

https://publikasiilmiah.ums.ac.id/bitstream/handle/11617/7351 /3\%20\%20Sayekti\%20Endah\%20Retno\%20Meilani.pdf?sequ ence $=1$

Mohammed, M. O., \& Taib, F. M. (2015). Developing Islamic banking performance measures based on Maqasid al-Shari'ah framework: Cases of 24 selected banks. Journal of Islamic Monetary Economics and Finance, 1(1), 55-77.

Mutia, E., \& Musfirah, N. (2017). Pendekatan Maqashid Shariah Index Sebagai Pengukuran Kinerja Perbankan Syariah di Asia Tenggara. Jurnal Akuntansi dan Keuangan Indonesia, 14(2), 181-201.

Nienhaus, V. (2012). Human resource management of Islamic banks: Responses to conceptual and technical challenges. In S. Archer \& R. A. A. Karim (eds.), Islamic Finance: the Regulatory Challenge (pp. 379-399). https://doi.org/10.1002/9781118390443.ch20

Pathan, S., Skully, M., \& Wickramanayake, J. (2007). Board size, independence and performance: an analysis of Thai banks. Asia-Pacific Financial Markets, 14(3), 211-227.

Perrini, F., Russo, A., Tencati, A., \& Vurro, C. (2011). Deconstructing the relationship between corporate social and financial performance. Journal of Business Ethics, 102(1), 5976.

Sarkar, J., Sarkar, S., \& Sen, K. (2012). A corporate governance index for large listed companies in India. Pace University Accounting Research Paper(2012/08). WP-2012-009. Retrieved from http://www.igidr.ac.in/pdf/publication/WP2012-009.pdf

Srairi, S. (2015). Corporate governance disclosure practices and performance of Islamic banks in GCC countries. Journal of Islamic Finance, 176(3132), 1-17.

Tabash, M. I. (2019). An Empirical Investigation on the Relation between Disclosure and Financial Performance of Islamic Banks in the United Arab Emirates. Journal of Asian Finance, Economics and Business, 6(4), 27-35. https://doi.org/10.13106/jafeb.2019.vol6.no4.27

Tandelilin, E., Kaaro, H., Mahadwartha, P. A., \& Supriyatna, S. (2007). Corporate governance, risk management and bank performance: Does type of ownership matter. EADN Individual Research Grant Project, 34, 115-118. 
ul Qayyum, N., \& Norren, U. (2019). Impact of Capital Structure on Profitability: A Comparative Study of Islamic and Conventional Banks of Pakistan. Journal of Asian Finance, Economics and Business, 6(4), 65-74. https://doi.org/10.13106/jafeb.2019.vol6.no4.65

Usman, N., Andriyani, L., \& Pambuko, Z. B. (2019). Productivity of Islamic Banks in Indonesia: Social Funds versus Financial Funds. Journal of Asian Finance, Economics and Business, 6(3), 115-122.

https://doi.org/10.13106/jafeb.2019.vol6.no3.115

Vinnicombe, T. (2010). AAOIFI reporting standards: Measuring compliance. Advances in Accounting, 26(1), 55-65.

Wahyudi, S., Sari, S. P., Hersugondo, H., \& Udin, U. (2019). Capital Adequacy Ratio, Profit-Sharing and Return On Asset: Case Study of Indonesian Sharia Banks. Wseas Transactions on Business and Economics, 16, 138-144.

Weir, C., Laing, D., \& McKnight, P. J. (2002). Internal and external governance mechanisms: their impact on the performance of large UK public companies. Journal of Business Finance \& Accounting, 29(5-6), 579-611. 